\title{
Lennart Hellspong \& Per Ledin: Vägar genom texten. Handbok $i$ brukstextanalys. Lund: Studentlitteratur, 1997
}

Et meget centralt område i danskfaget er læsning af ikke-skønlitterære tekster, og det gælder alle niveauer lige fra folkeskolen til universitetet. Dette er et resultat af studenteroprøret i slutningen af 60'erne og begyndelsen af 70'erne, hvor man revolterede mod det, man så som danskfagets fastlåsning i historiske discipliner (sproghistorie, dialektologi, runologi, onomastik). I stedet $\emptyset$ nskede man undervisning i tolkning af "hverdagens tekster" for at kunne vise (eller "gennemskue") deres funktion i samfundet. At denne fornyelse fik succes kan man bl.a. se i det faktum, at "sproglig tekstforståelse" eller "pragmatisk teksttolkning" i lang tid og på flere universiteter har været det eneste indslag af sprogfag i uddannelsen af gymnasielærere. Succesen skyldtes selvfølgelig ikke kun revolten mod "det gammeldags", men også at forandringer i samfundet medførte en eksplosiv stigning i mængden af ikke-litterære tekster og dermed en forøgelse af deres betydning - en tendens, som ikke er blevet mindre i de årtier, som er gået siden. Tendensen er også slået igennem i de øvrige nordiske lande, selv om man her ikke har været helt så hurtige til at forkaste den traditionelle nordistik, som man var (mange steder) i Danmark.

Men står de ikke-litterære tekster stadig centralt placeret, er der imidlertid sket meget med mål og metoder; den stærkt politiserede "ideologikritik", hvor det først og fremmest drejede sig om at vise tekstens undertrykkende og klassemæssige funktion, er fortrængt til fordel for en undersøgelse af tekstens egenart, dens struktur og retorik, og hvordan dette tjener tekstens kommunikativ mål. Og samtidig er der sket en utrolig udvikling af de analysemetoder, der anvendes, såvel de lingvistiske som de massekommunikative.

Denne udvikling og det faktum, at "brugstekstanalyse" har en så central plads i modersmålsundervisningen, afføder et stort behov for nye lærebøger, samtidig med at det stiller store pædagogiske krav: hvordan behandle så stort et område, uden at bogen svulmer op; hvordan vælge teksteksempler; hvordan prioritere mellem teorigennemgang og tekstanalyse osv. Lennart Hellspong og Per Ledin, begge fra Institutionen för nordiska språk ved Stockholms universitet, har med Vägar genom texten givet et bud på, hvordan en sådan lærebog kan se ud - og et meget vellykket sådant.

Bogen er opdelt i tre hoveddele: først en optakt, som diskuterer tekstbegrebet, genrer m.m.; dernæst en analysedel, hvor tekstmodellen bygges op, og analysen af formen, indholdet, stilen og relationen gennemgås; og en tillempningsdel, hvor hermeneutik, retorik og kritik fremstilles og diskuteres. Hvert kapitel afsluttes med en sammenfatning, som i punkter viser de spørgsmål, man bør stille til teksten. Alene dette greb er nok til at give bogen en høj anvendelighedsgrad; samler man alle disse sammenfatninger, har man en fremra- 
gende checkliste til en analyses mulige progression og en garant for, at man ikke overser et vigtigt punkt. Bogen afsluttes med en ræsonneret litteraturgennemgang for hvert kapitel, hvilket også har gjort at selve teksten er blevet holdt ren for fodnoter og at litteraturhenvisningerne undervejs er blevet begrænset til det mest nødvendige. På den måde har man kunnet holde en flydende stil, som gør bogen letlæst.

Gennemgangen af tekstmodellen og analysen indledes med fire gode råde til den student, som skal lave en analyse af en fagtekst: 1. Vær fleksibel og tilpas analysen til den aktuelle tekst. 2. Sorter med omtanke, tag ikke alt med. 3. Vær kreativ, anvend ikke modellen mekanisk, men til at generere idéer. 4. Sammenfat, lav løbende synteser af hvad man har set, så analysen ikke fortaber sig i usammenhængende detaljer. Min erfaring er, at det er utroligt vigtigt at indprente de studerende, at enhver god analyse er "objektfølsom", men at man er oppe mod stærke $\emptyset$ nsker fra de studerende, der vil have færdige analysemaskiner, som man kan køre en hvilken som helst tekst igennem. Faktisk er det vel den vigtigste del af det at lære sig at analysere, at man lærer sig lydhørhed over for tekstens egenart og dermed for, hvad der er relevant (i teksten og dermed i analysemodellen). Her kunne forfatterne godt tydeligere have fremhævet, at lydhørheden er noget som trænes frem gennem at analysere, og at det derfor er vigtigt at analysere mange og forskellige tekster - hvilket jo desværre er et faktum, der sjældent tages hensyn til, når kurser skal tilrettelægges.

Under gennemgangen af konteksten skelnes der mellem situationskontekst, som vedrører den aktivitet og det mål, teksten indgår i, deltagerne og kommunikationsmåden (kode/jargon); intertekstuel kontekst, såvel den vertikale (historiske) som den horisontale (samtidige), og kulturel kontekst, som omfatter den materielle kultur, den sociale organisation og den åndelige kultur. Behandlingen af de forskellige konteksttyper er ret kort og på ingen måde udtømmende, men den opfylder sin funktion i forhold til de studerende, nemlig at pege på faktorer, som man så i hver enkelt analyse må afgøre relevansen af. Vigtig er også påpegningen af, at et samfunds kultur aldrig er uniform og uden revner, men at der hele tiden findes en strid, som påvirker teksten. Også det korte afsluttende analyseeksempel er velvalgt og viser forfatternes evne til at finde nye, aktuelle og til tider overraskende objekter: i dette tilfælde et uddrag af en dialog på en computer chat-linie.

Bogens hovedvægt ligger i de to følgende kapitler, "7. Formen - den textuella strukturen" og "8. Innehållet - den ideationella strukturen". Her gennemgås leksikogrammatik, tekstbinding, komposition, tema, propositioner, modalitet og perspektiv. Det leksikogrammatiske niveau opsummeres i tre såkaldte dimensioner, som kan bruges til at karakterisere tekster med (dog, som forfatterne påpeger, under forudsætning af at man iagttager en vis forsigtighed og tager højde for teksten og kontekstens særtræk). De tre dimensioner er hhv. 
nominal/verbal, specifik/almen og abstrakt/konkret. De to første vedrører informationstætheden, den tredje graden af nærvær; den første går på udtrykssiden, de to sidste mere på indholdssiden. På denne måde får forfatterne dels vist, hvorledes enkeltobservationer af fx fordelingen mellem substantiver og verber, nominalfraser, sammensatte substantiver, forvægt, tids- og rumsadverbialer m.m. spiller sammen og karakteriserer en tekst, dels hvordan udtryk og indhold hænger sammen og hvordan dette bør komme frem i analysen.

Forskellige former for tekstbinding gennemgås: referensbinding, tematisk binding, konnektivbinding og retorisk binding. Selv om gennemgangen er kort, er det et godt eksempel på, hvordan nyere undersøgelser inden for tekstlingvistik kan og bør inddrages i en lærebog, og specielt er inddragelsen af den retoriske binding interessant. Her knyttes en forbindelse mellem tekstlingvistik og retorik, som er naturlig, men som desværre har været fraværende i mange fremstillinger. Også på dette område kan forfatterne således siges at være på omgangshøjde med de diskussioner, som foregår inden for området, i stedet for blot at trække de samme gamle heste ud af stalden.

I kapitel 8 om indholdet, eller som forfatterne kalder det: den ideationelle struktur, beskrives tre hovedindslag: temaer, som er hvad teksten bevæger sig om eller handler om; propositionerne, som er hvad teksten kommer frem til, og perspektiverne, som er de generelle synspunkter, som påvirker både temaer og propositioner. Centralt i analysen af tematikken er det faktum, at to personer kan nå frem til forskellige resultater for samme tekst, og at analysen følger tekstens lineære forløb i fastlæggelsen af sætningers og afsnits tema og tekstens makrotema. Begge dele er pædagogisk set vigtige. Det første punkt for at understrege, at en analyse altid indebærer valg, som er bestemmende for analysens resultat, og at der derfor ikke findes nogen "facitliste" for hver enkelt tekst. Her kunne forfatterne gerne have gået lidt ind i den teoretiske diskussion om fortolkningers validitet og spørgsmålet om fortolkning vs. overfortolkning; et centralt problem i undervisning i tekstanalyse er netop at forklare, hvordan man kan forkaste visse fortolkninger uden af den grund at sidde inde med den "korrekte" tolkning. Det andet punkt er vigtigt for at gøre opmærksom på, at analyse ikke blot består i at slå ned på det, man selv umiddelbart mener er det vigtigste, men at selve processen i sig kan lede til resultater, som man ville overse, hvis man gik direkte efter det "selvindlysende".

Bogens afsluttende afsnit har overskriften "Tillämpning" og indeholder tre kapitler om hhv. hermeneutik, retorik og kritik. Her knyttes forbindelsen mellem den tekstnære analyse, som de foregående kapitler har fremlagt, og de mere overgribende, teoretiske tolkningsteorier og målsætninger. Hermeneutikken og retorikken behandles ret kortfattet, men alene det at de har fået plads i en grundbog i brugstekstanalyse er prisværdigt. Her gøres et alvorligt fors $\varnothing \mathrm{g}$ 
på at inddrage de ofte ret "tunge" og filosofiske aspekter af (især) hermeneutikken og vise at de kan anvendes også i mere jordnære sammenhænge. Størst plads får dog kritikken, som her skal forstås i retning af en udogmatisk udgave af den kritiske diskursanalyse, der "söker en förståelse av hur texten å ena sidan formas av sina sociala förutsättningar och å andra sidan bidrar till att omforma de sociala förhållanden som den har sin grund i”. Dette eksemplificeres med to analyseeksempler: en informationsbrochure i forbindelse af afstemningen om EU-medlemskab, og Socialstyrelsens brochure om organdonation. Selv om også disse eksempler er ret kortfattede, giver de en udmærket fornemmelse af, hvad en kritisk analyse kan fokusere på.

Om Vägar genom texten kan man generelt sige, at den giver en fin introduktion til analysen af ikke-skønlitterære tekster, og at såvel dens eksempelvalg som dens faglige indfaldsvinkler og strukturering af stoffet er forfriskende og pædagogisk. Eneste kritikpunkt er faktisk, at bogen indeholder et for Studentlitteratur ualmindeligt højt antal korrekturfejl, men det kan vel ændres til andenudgaven.

Orla Vigs $\varnothing$ 